Doc. dr. Nena

Mijoč,

Filozofska

fakulteta

Lili Mistral, študentka

Filozofska

fakulteta

\title{
DOGOVOR O SAMOIZOBRAŽEVANJU Dogovor o samoizobraževanju, osebni učni načrt, učni dogovor ali učna pogodba?
}

\section{POVZETEK}

Kar štirje izrazi so na voljo za podobna prizadevanja oziroma metodo izobraževanja, ki poveča učinkovitost izobraževanja odraslih ljudi. $V$ prispevku avtorici utemeljita prevod izraza »learning contract « $v$ dogovor o samoizobraževanju kot metodo v izobraževanju odraslih, ki so jo začeli pogosteje tudi v institucijah za formalno izobraževanje uporabljati v ZDA že okoli leta 1970. $V$ času vseživljenjskega učenja, ko naj bi se vsakdo znal tudi uspešno učiti iz najrazličnejših virov, je še toliko pomembnejše, da znamo svoje izobraževanje načrtovati. Te kompetence razvija ravno metoda dogovora o samoizobraževanju, ki je že osvojila uspešna učeča se podjetja, počasi pa si utira pot tudi v formalno izobraževanje.

Dogovor o samoizobraževanju je pisni dogovor med najmanj dvema osebama, kjer bo ena oseba svetovala, druga pa se bo samoizobraževala. Kako pripravimo dogovor in kdo je odgovoren za njegovo pripravo in izpeljavo? $Z$ dogovorom o samoizobraževanju (SI) v pisni obliki pojasnimo cilje, tehnike, strategije in način evalvacije izobraževalnega procesa. Hkrati pa izobraževanje tudi časovno opredelimo. Je močno motivacijsko sredstvo, ker izhaja iz potreb osebe, prilagajamo ga interesom in učnemu slogu osebe. Predvsem je to primerna metoda za pridobivanje kompetenc, za terensko delo in izkustveno učenje na delovnem mestu. Dogovor o SI je zelo primeren in učinkovit tudi za samostojen akademski študij, še posebej, kadar ga kombiniramo z metodo pogovora in diskusije.

Ključne besede: izobraževanje, samoizobraževanje, dogovor o samoizobraževanju, osebni izobraževalni načrt, učna pogodba, učni cilji

a začetnika metode dogovora o samoizobraževanju $v$ literaturi navajajo andragoga Malcolma Knowlesa. Njegovo delo Using Learning Contracts je prvič izšlo leta 1986 in nato še v ponatisu leta 1991. Knowles meni, da je potrebno odrasle spodbujati, naj prevzamejo več odgovornosti za svoje izobraževanje. Veliko se je ukvarjal z odraslimi, ki so se izobraževali ob delu, zato se je koncept do- govora o samoizobraževanju najprej razvijal v izobraževalnih ustanovah za odrasle (Knowles, 1991 (1986), in Boak, 1998).

Učinkovitost izobraževanja je vselej odvisna od pripravljenosti in motiviranosti posameznika, kadar gre za vodeno samoizobraževanje, pa tudi od institucije, ki skrbi za evalvacijo znanj in druge faze $\mathrm{v}$ procesu izobraževanja. Da bi prilagodili izobraževanje spremenljive- 
Izobraževalni pristopi se vse bolj odmikajo od tradicionalnega odnosa med učiteljem in učencem ter od predavalnice $\mathrm{v}$ svet, $\mathrm{v}$ katerem ljudje živijo in delajo. Razvoj trga dela in potreba po vseživljenjskem učenju zahtevajo vedno učinkovitejše načine osvajanja znanja. Tradicionalni izobraževalni sistem ima več pomanjkljivosti, znanje je slabo izkoriščeno, hitro zastareva, pa tudi zaposleni velikokrat ne znajo uporabljati v šolah naučenih veščin in znanj.

mu delovnemu ritmu in posebnim pogojem, v katerih živijo in delajo odrasli (oddaljenost od delovnega mesta, družine z majhnimi otroki ali osebe, potrebne vsakdanje pomoči), so univerze in druge organizacije pripravljene posameznikom ponuditi možnost samostojnega izobraževanja. Odrasli morajo prevzeti odgovornost za svoje izobraževanje, ga sami načrtovati, izvajati in tudi sami nadzirati. Uporaba dogovorov o samoizobraževanju je v poslovnem svetu že dobro poznana kot uspešna metoda razvoja vodstvenih kadrov in spodbujanja delovne učinkovitosti, je pa res, da jo večinoma poznajo pod pojmom osebni učni načrt ali učna pogodba. Oba izraza sta sprejemljiva, vendar menimo, da bi prevod izraza »learning contract« vsebinsko in strokovno bolj ustrezal, če bi ga prevajali kot dogovor o samoizobraževanju. V slovenski literaturi se navadno prevaja kot individualni učni načrt ali učenje po dogovoru oz. pogodbi (Jelenc, 1991) oziroma učna pogodba (Brečko, 2003). Vsi izrazi le delno opredeljujejo metodo, ki jo vse pogosteje uporabljamo v neformalnem izobraževanju odraslih, še posebej v učečih se podjetjih. Vsi izrazi so nakazani že v delih $\mathrm{M}$. Knowlesa, ki je prvi natančneje opredelil metodo dogovora o samoizobraževanju (Knowles, Self-directed learning, 1975 (1980), in Knowles, Using learning contracts, 1986 (1991)).
Prvi prevod, tj. individualni učni načrt ali natančneje osebni izobraževalni načrt, nakazuje, da gre za načrt izobraževanja, ki ga pripravimo za posameznika, ali ga pripravi posameznik sam. Pri tem je načrt $\mathrm{v}$ celoti prilagojen posamezniku in torej $\mathrm{v}$ celoti podpira individualizacijo izobraževanja. Mentor in oseba, ki se uči, se na osnovi predloga osebnega izobraževalnega
Oče dogovora o samoizobraževanju oz. učni pogodbi je M. Knowles. načrta pogovarjata in posledično dogovorita o načrtu izobraževanja, ki sloni na ugotovljenih izobraževalnih potrebah in v katerem so jasno opredeljeni cilji, strategije, metode in tehnike izobraževanja, kjer predvidimo, kaj bomo ocenjevali, kdo bo ocenjeval in po katerih kriterijih, ter končno, kjer tudi časovno opredelimo, kako bo potekalo izobraževanje in kdaj bo zaključeno.

Dogovor je vselej pisni in v njem je tudi jasno razvidno, kdo je odgovoren za posamezne stopnje v izobraževanju. Obe stranki ga podpišeta in s tem potrdita svojo pripravljenost za sodelovanje $\mathrm{v}$ procesu.

Knowles eksplicitno poudarja, da ne gre za pogodbo v pravnem smislu, četudi je na prvi pogled pisni dogovor tej podoben. $\mathrm{V}$ tej »pogodbi« niso opredeljene kazni ob neizpolnjevanju in tudi odgovornosti so bolj implicitno kot eksplicitno določene. Vprašanje je, čemu se je potem Knowles odločil za uporabo termina učna pogodba, saj v resnici to ni. In tudi po našem mnenju ne gre zgolj za individualizacijo in tudi ne za kakršnokoli učenje ( $v$ ožjem ali širšem smislu), temveč gre za načrten, strukturiran in $\mathrm{k}$ cilju usmerjen proces učenja, ki mu v slovenščini pravimo izobraževanje (Krajnc, 1979, Mijoč, 2005). Tudi pogajanja so sestavni del dogovarjanja, vendar niso nujno potrebna, kadar posameznik, ki se izobražuje, pripravi pisni dogovor tako kakovostno, da ga lahko mentor, vodja ali svetovalec v celoti potrdi. 
Ostane nam še, da utemeljimo uporabo termina samoizobraževanje in ne zgolj izobraževanje. Najprej moramo potegniti ločnico med učenjem in izobraževanjem ter upoštevati definiciji učenja in izobraževanja. Učenje je relativno trajno, progresivno spreminjanje osebe na temelju izkušenj. Poteka lahko kjerkoli: pri delu, v prostem času, ob obisku gledališča, kina, ob poslušanju radia, televizije, iskanju informacij preko

Je dogovor o samoizobraževanju nova oblika ali metoda izobraževanja? računalnika, srečanja z znano ali neznano osebo. Preden prikažemo uporabo in elemente dogovora o samoizobraževanju, pojasnimo še njegovo umestitev med metode izobraževanja odraslih. Lahko bi se

vprašali, ali gre zgolj za nek nov pripomoček, tehniko, ki pripomore $\mathrm{k}$ učinkovitejšemu izobraževanju? Ali gre morda za novo obliko ali metodo izobraževanja? V izobraževanju odraslih se namreč srečujemo s številnimi metodami; metoda predavanja, metoda pogovora, metoda diskusije, metoda primera, od metode igranja vlog do metode primera - te sodijo $\mathrm{k}$ metodam skupinskega izobraževanja odraslih. Poznamo pa še metode individualnega in metode množičnega vzgojnoizobraževalnega dela. Kam torej uvrščamo dogovor o samoizobraževanju?

Poglejmo, kaj uvrščamo med metode individualnega vzgojnoizobraževalnega dela:

- metode dopisnega izobraževanja,
- metode izobraževanja na daljavo,

- metode individualnega izobraževanja $v$ osebnem stiku z drugo osebo,

- metode samostojnega izobraževanja ali metode samoizobraževanja (Krajnc, 1979). Med metodami individualnega izobraževanja $v$ osebnem stiku $z$ drugo osebo so najbolj poznane oblike konzultacije, inštrukcije, mentorstvo in dialog. Metode individualnega izobraževanja dajejo najpopolnejšo vzgojno komunikacijo. Dvosmerne komunikacije potekajo intenzivno, oba sogovornika reagirata neposredno. Metode samoizobraževanja se razlikujejo glede na izvor, ki ga posameznik uporablja za pridobivanje novih spoznanj, opazovanje različnih aktivnosti, učenje s pomočjo lastne prakse in izkušenj, izobraževanje s pomočjo sistematičnega zasledovanja masovnih medijev, metodo samostojnega študija teksta, izobraževanje s pomočjo učnih pripomočkov, učenje v pogovoru ali diskusiji $\mathrm{z}$ drugimi ljudmi. Metode samoizobraževanja $v$ celoti slonijo na razvitih miselnih sposobnostih, na zmožnosti ljudi za logično sklepanje, za sintetično-analitično, kritično mišljenje in ustvarjalno mišljenje ter za take miselne funkcije, ki človeka v procesu učenja osvobajajo, da potrebuje vedno manj tuje pomoči (Krajnc, 1979).

S tega vidika lahko zaključimo, da je dogovor o izobraževanju kot metoda izobraževanja odraslih kombinacija individualnega izob-

Če bi šlo zgolj za katerikoli izobraževalni proces, bi lahko predvidevali, da bodo izobraževalni cilji doseženi tudi v primeru, ko se oseba vključi v skupinsko izobraževanje. Tedaj bi - na primer $\mathrm{z}$ vidika razvoja človeških virov - zadostovala pogodba o tem, da se bo oseba vključila $\mathrm{v}$ neko formalno ali neformalno izobraževanje oziroma usposabljanje. Natančno $\mathrm{v}$ tem pomenu smo tudi doslej uporabljali izraz »učna pogodba«, ki je tako tudi opredeljen v Terminologiji izobraževanja odraslih (Jelenc, 1991) in v zakonskih aktih.' Tudi to je eden izmed vzrokov, da smo se odločili za navedni prevod in ne za prevod »učna pogodba«. Dogovor o samoizobraževanju bo torej smiselno pripraviti, kadar se oseba izobražuje predvsem po individualnem načrtu in ne, kadar že $\mathrm{z}$ vključevanjem v skupinske oblike izobraževanja doseže predvidene izobraževalne cilje. 
raževanja $\mathrm{v}$ osebnem stiku $\mathrm{z}$ drugo osebo in samoizobraževanja.

Ko govorimo o metodi dogovora o samoizobraževanju, seveda ne mislimo na čisto samoizobraževanje, kjer bi oseba povsem v osami in neodvisno od drugih študirala tekste in uporabljala druge pripomočke za samoizobraževanje. Mislimo na tisto obliko samoizobraževanja, kjer posameznik prevzame odgovornost za svoje izobraževanje in pripravi načrt izobraževanja tako, da je prilagojen njegovemu učnemu slogu, njegovim interesom in pogojem, v katerih se izobražuje. Tu lahko poteka izobraževalni proces precej neodvisno od drugih oseb. Pri zastavljanju operativnih ciljev in evalvaciji pa je lahko proces izobraževanja bolj ali manj v sozvočju $\mathrm{z}$ institucionaliziranimi oblikami izobraževanja.

Pri načrtovanju izobraževanja se najprej odločamo za obliko, ki je opredeljena tudi $\mathrm{z}$ zunanjimi, nepedagoškimi dejavniki, kot so npr. pogoji za izvedbo izobraževanja, pogoji tistih, ki se izobražujejo, ter pogoji tistih, ki vodijo izobraževalni proces, in se kasneje podrobneje odločamo za najprimernejšo metodo (Mijoč v Jelenc idr., 1992). V tem smislu bi dogovor o samoizobraževanju lahko šteli $\mathrm{k}$ oblikam izobraževanja, kot so npr. izobraževanje na daljavo, večerne šole, poletne šole, seminarji, tečaji ipd. Vendar dogovor o samoizobraževanju sklenemo ravno zato, ker te oblike zaradi svoje časovne neprilagojenosti (pa tudi včasih zaradi togega pristopa, kot je npr. zgolj frontalni pouk) ne ustrezajo odraslemu, ki želi tako kot na drugih področjih življenja ostati samostojen in aktiven partner tudi v izobraževalnem procesu. Torej bomo dogovor o samoizobraževanju uporabili tudi v okviru formalnega izobraževanja, tudi npr. pri usposabljanju na delu ali kadar oseba ne more ali ni pripravljena obiskovati specifičnega tečaja. Ali pa tudi v primeru neformalnega izobraževanja, kadar je npr. študijski krožek na podobno temo za nekatere posameznike preveč po- časna ali prezahtevna pot do novih spoznanj. Zaradi navedenih razlogov smo se odločili uporabiti izraz »metoda dogovora o samoizobraževanju « ali krajše kar metoda dogovora o SI. Po našem mnenju izraz dokaj natančno opredeli proces, $s$ katerim določimo, da gre za dogovor med najmanj dvema osebama in da gre za samoizobraževanje. Knowles trdi, da lahko poteka dogovarjanje $v$ dvojici, na primer med mentorjem in udeležencem izobraževanja. Pogosto se $v$ ta proces vključi tudi organizator izobraževanja oziroma vodja ali predstavnik institucije, ki bo formalno potrdila pridobljeno znanje, kadar je to potrebno. Nekateri avtorji (Cafarella v Galbraight, 1989) omenjajo tudi možnost, da dogovor sklenemo s samim seboj, vendar bi v tem primeru lažje govorili o individualnem načrtu izobraževanja ali načrtu samoizobraževanja. Dogovor o samoizobraževanju pa natančneje določi tudi, katere izobraževalne cilje bo oseba dosegla, česa se bo učila, na kakšen način in kako bo znanje evalvirano ter kako bo časovno potekalo.

\section{POZNAVANIE IN UPORABA METODE DOGOVORA O SAMOIZOBRAŽEVANJU V SLOVENIJI}

Da bi ugotovili, koliko je metoda prisotna $\mathrm{v}$ našem prostoru in ali jo kaže raziskovati, smo izvedli kratko pilotsko raziskavo na naključnem vzorcu. ${ }^{2}$ Anketirancem smo zastavili tri vprašanja: Ali poznajo metodo, ki se imenuje učna pogodba, dogovor o samoizobraževanju oz. individualni učni načrt (angl. learning contract)? Ali to metodo tudi uporabljajo? Kako si jo pojasnjujejo?

$\mathrm{Na}$ vsa tri vprašanja je pozitivno odgovorila samo ena oseba, in sicer: »Navedeno metodo uporabljamo že dalj časa, čeprav je ne označujemo strogo kot 'pogodbo', temveč kot dogovor med profesorjem in študentom. Iz- 
kušnje so pozitivne in metode se pogosto poslužujemo, saj je pri našem delu (izredni študij - odrasli, zaposleni študenti) včasih celo nujno potrebna.«

Anketiranci, ki so odgovorili, da metode ne poznajo (takšnih odgovorov je bilo 6), predvidevajo, da bi lahko metoda pomenila naslednje:

- na kakšen način se z nekom dogovoriš, da se bo izobraževal sam,

- dve strani (učitelj-učenec, mentor-mentoriranec) se dogovorita za sodelovanje na način, da učenec večinoma dela samostojno, mentor/učitelj ima vlogo svetovalca: kratke predstavitve oz. vodenje skozi delovne vsebine, pomoč pri morebitnih nejasnostih oz. odgovarjanje na vprašanja. Podpišeta učno pogodbo, v kateri je zapisano, kaj in kako se bo učenec učil, do kdaj se mora kaj naučiti, na kakšen način bo osvojeno znanje predstavil in kako se bo to ovrednotilo/ocenilo,

- verjetno je to dogovor, da bo določena oseba samoiniciativno dopolnjevala svoje znanje na določenem področju in da bo sledila ter obvladovala vse novosti na tem področju s

Kaj je dogovor o samoizobraževanju, kdaj je primeren, kako ga oblikujemo?

Dogovor o samoizobraževanju je kombinacija individualnega izobraževanja $v$ osebnem stiku z drugo osebo in samoizobraževanja. Uporablja se $\mathrm{v}$ podjetjih, na fakultetah, na višjih in visokih šolah. $\mathrm{V}$ izobraževalnih ustanovah $v$ ZDA dogovor o samoizobraževanju redno uporabljajo zadnjih 20 let. V ZDA kreditni sistem namreč dopušča oblikovanje osebnega izobraževalnega načrta. Poskusi uporabe dogovora o izobraževanju segajo še kakšno desetletje nazaj, saj je Berte leta 1975 zbral več začetnih izkušenj o t. i. »learning contract « na ameriških šolah (Berte, 1975). ${ }^{3}$ celega sveta,

- predstavljam si to kot dogovor med ustanovo in učiteljem, kjer dobi učitelj na razpolago določena sredstva $\mathrm{z}$ namenom samoizobraževanja, da lahko sledi razvoju stroke,

- izobraževalni cilj kandidat doseže s samoizobraževanjem in o tem prejme ustrezno javno listino. Aktivnosti potekajo po metodi, ki je predhodno dogovorjena. Metodi sledita mentor in kandidat. $\mathrm{O}$ aktivnostih se oba pisno dogovorita.

Dva respondenta metodo poznata, vendar je pri svojem delu (dosedaj) še nista uporabila. Delo s pomočjo metode dogovora o samoizobraževanju si predstavljata na naslednja načina:

- pred začetkom izobraževalnega procesa se predavatelj in študent dogovorita o določenih delih kataloga znanj, pri katerih bi študent cilje lahko dosegel skoraj $v$ celoti samostojno. Pri tem točno definirata cilje, pripomočke za doseganje ciljev in pomoč, ki jo bo pri tem nudil predavatelj. Nujen je seveda tudi dogovor o terminih za doseganje ciljev, ker morajo biti ti usklajeni s celotnim katalogom znanj. Nadaljnji dogovori o samoizobraževanju so odvisni od uspešnosti pri doseganju ciljev,

- metodo bi lahko uporabil tudi pri svojem poučevanju na višji šoli. Predvsem bi bila uporabna pri izrednih študentih, kjer zaradi pomanjkanja časa nekateri ne hodijo na predavanja. Pri slednjih bi bila to odlična rešitev za spoznavanje snovi predavanj, ki jo sicer ne pregledajo.

Analiza odgovorov je pokazala, da je z metodo seznanjenih le malo respondentov. Zato s slučajnostnim vzorcem in kvantitativno obdelavo rezultatov verjetno ne bi mogli dobiti kakšnih reprezentativnih odgovorov. Bolj bi prišla v poštev kvalitativna analiza primerov tam, kjer metodo že uspešno uporabljajo. 
Dogovor o samoizobraževanju je dokument, s katerim si pomagamo pri načrtovanju izobraževalnega procesa oziroma študijskega projekta. Je pisni dogovor, v katerem se študent in svetovalec (včasih tudi institucija ali organizacija in dobimo tripartitni dogovor) dogovorita o poteku procesa individualnega izobraževanja.

Dogovor o samoizobraževanju je v bistvu načrt izobraževanja, ki ga pripravi odrasli, ki se izobražuje, in s svojim podpisom potrdi tudi mentor. Omogoča nam, da se pri načrtovanju izobraževanja prilagodimo posameznikovim izobraževalnim potrebam, izkušnjam, predhodnemu znanju, interesom in pogojem posameznika. V tem smislu je dejansko oseba, ki se uči, v središču pozornosti. Primeren je predvsem, kadar imajo udeleženci zelo različno predznanje, izkušnje in izobrazbo. Prav pride tudi, kadar udeleženci ali študenti zaradi različnih razlogov in pogojev napredujejo $z$ različnim tempom. Posebej je primeren, kadar je izobraževanje zasnovano na individualnih projektih.

Dogovor o samoizobraževanju omogoča, da oseba tvorno sodeluje že $v$ procesu ugotavljanja potreb in pri določanju učne strategije in virov. Gre za dogovorjeni sporazum, kjer določimo, kaj in kako se bo posameznik izobraževal ter kako bo naučeno na koncu izobraževalnega procesa dokazal in pokazal. V bistvu je formalni pisni dogovor, $v$ katerem posamezni študent podrobneje opredeli, česa se bo naučil in kako se bo tega naučil, v ko-

Menimo torej, da priprava dogovora o samoizobraževanju poteka praviloma $v$ treh stopnjah, od katerih sta prvi dve nujni, tretja pa ni obvezna:

- priprava osebnega izobraževalnega načrta,

- pogovor, dopolnitev in podpis dogovora,

- oblikovanje in podpis pogodbe. likšnem času ter kako bomo ugotovili, da so cilji doseženi.

Dogovor lahko oblikujemo na dva načina:

- oseba sama oblikuje celoten dogovor - načrt je tako v celoti prepuščen posamezniku,

- večino dogovora oblikuje študent - cilji, standardi in vsebina izobraževanja so vnaprej postavljeni, poti za doseganje ciljev pa so prepuščene posamezniku.

Beseda dogovor pomeni, da je vse, kar je napisano, pomembno in sprejemljivo za obe stran$\mathrm{ki}$ - za študenta in za svetovalca ali mentorja, vodjo ali celo podjetje, institucijo. V vsakem primeru je dogovor dvostranska komunikacija in pri oblikovanju vedno sodeluje tudi svetovalec, mentor ali vodja.

\section{ELEMENTI DOGOVORA O} SAMOIZOBRAŽEVANIU

Ko smo v uvodu utemeljili dogovor o samoizobraževanju kot ustrezen prevod angleškega izraza »learning contract«, smo imeli pred očmi dejstvo, da večino dogovorov pripravi oseba, ki se namerava samostojno izobraževati. To ne drži vedno, ampak je možno, da oseba zaradi slabega predznanja in šibkih kompetenc za načrtovanje svojega učenja ne zmore sama pripraviti dogovora. Druga možnost je, da v organizaciji (delovni ali izobraževalni) že imajo nekaj primerov dogovo-
Pri dogovoru o samoizobraževanju je potrebna dvostranska komunikacija. rov, zato jih lahko dobi oseba na vpogled in potem dopolni ter prikroji svojim potrebam in pogojem. Pravzaprav je najbolje, če je to le mogoče, da najprej odrasel sam pripravi osebni izobraževalni načrt, saj se s tem v načrtovano dejavnost poglobi in upošteva svoje potrebe, predznanja, izkušnje, interese in pogoje. To močno vpliva na notranjo motivacijo in razvija posameznikovo sposobnost načrto- 
vanja lastnega izobraževanja. Četudi je načrt zelo okvirno narejen, vendarle prispeva $\mathrm{k}$ lastni angažiranosti posameznika in ga prisili, da anticipira in se vživlja v predvideno izobraževalno dejavnost. Ko je osnutek pripravljen, sledi pogovor z mentorjem (lahko je to svetovalec, vodja ali strokovnjak za določeno vsebinsko področje) in natančnejša določitev načrta. Temu sledi potrditev z obojestranskim podpisom. Med pripravo načrta se lahko dogovor še dopolnjuje in spreminja. Knowles predlaga, da omogočimo spreminjanje dogovora le $\mathrm{v}$ začetku procesa izNajzahtevnejše je oblikovanje pravih ciljev. vajanja dogovora, kasneje pa le izjemoma ob nepredvidenih dogodkih.

Kadar gre za nujnost formalne potrditve dogovora, je potrebno dogovor še podrobneje opredeliti in ga dopolniti recimo še s »tretjim podpisnikom« in $s$ finančnim načrtom oziroma »proračunom učne pogodbe « (Brečko, 2003, str. 87).

$\mathrm{V}$ večini primerov je najzahtevnejša priprava osebnega izobraževalnega načrta, pri kateri praviloma dejavno sodeluje oseba, ki se bo izobraževala, in mentor. Preden dosežemo dogovor, je potreben najmanj eden ali več pogovorov, odvisno pač od izkušenj in usposobljenosti obeh sodelujočih.

\section{OPERATIVNI UČNI CILJI}

Operativni učni cilji so najpomembnejši del dogovora o samoizobraževanju. Od ciljev so odvisni vsi nadaljnji elementi dogovora. Učni cilji se med izvedbo dogovora lahko po potrebi tudi dopolnijo, vendar le v obojestranskem dogovoru in s tehtnim razlogom.

Učni cilji naj vsebujejo naslednje značilnosti:

- razumljivost, ki pomeni smiselno upoštevanje izobraževalnih potreb,

- merljivost: ko cilje določamo, moramo že imeti $\mathrm{v}$ mislih, kako jih bomo merili, in paziti predvsem na to, da bo merjenje objektivno,

- časovno omejenost: cilje moramo natančno časovno omejiti $\mathrm{z}$ datumom in ne zgolj $\mathrm{z}$ mesecem ali celo letom zaključka; vmesne cilje $\mathrm{v}$ dogovoru lahko opredelimo tudi intervalno,

- sprejemljivost: učne cilje določi študent, druga stran pa mu strokovno pomaga; načelo dogovora je, da oseba sodeluje pri določanju ciljev in jih sprejme za osebne cilje,

- predstavljati morajo izziv: ne smemo se prenagliti in ciljev zastaviti previsoko, ker lahko povzročimo stres; na drugi strani pa ne smemo postavljati ciljev preohlapno; cilji morajo biti motivacijski dejavnik, tako da s pomočjo dogovora dosežemo napredek.

\section{VIRI IN STRATEGIJE}

$\mathrm{Z}$ dobrimi viri in strategijo si bomo olajšali proces, od njega dobili največ in dosegli cilje dogovora o samoizobraževanju. Odločilno vlogo ima svetovalec, saj ima največ izkušenj

Vrste končnih izdelkov kot dokazilo o doseganju ciljev so lahko (Brečko, 2003): seminarska naloga ali esej, poročilo, predstavitev pred skupino, evalvacijsko poročilo, predavanje $\mathrm{z}$ demonstracijo, avdio-vizualna ali video predstavitev, študija primera, bibliografija s komentarji, grafično oblikovanje, poslovni načrt, referat za konferenco, ustni ali pisni izpit, računalniški program, skice, osnutki, diagrami, smernice za vodjo razprave, kritična analiza, posnetki intervjujev, fizični pripomočki (npr. na delovnem mestu), poročilo o vodenju, miselni vzorci, zapisniki, članki v časopisih ali revijah, fotografije ali diapozitivi, letaki, projektni načrt, intervju, raziskovalna naloga, poročilo, rešitve problemov, priročnik za izvajanje dela/procesa, dnevnik, poročilo o delovnih izkušnjah, umetniški izdelki. 
in lahko odraslega usmeri $\mathrm{k}$ pravim virom in strategijam.

Učni viri niso zgolj strokovna literatura, temveč $\mathrm{k}$ njim prištevamo vse, kar lahko poveča znanje, razumevanje ali spretnosti. Navedimo še npr. naslednje možnosti: seminarji in konference, delavnice in tečaji, knjige in periodični tisk, seminarsko in konferenčno gradivo, vladne ali druge uradne publikacije in dokumenti, zgoščenke in drugi elektronski mediji, avdiovizualni pripomočki, poklicna združenja, izvedenci za določeno področje, družinski člani in prijatelji, TV in radio, individualne ure in inštrukcije, zapiski o študijah primerov, sodelavci in sošolci, vodilni strokovnjaki in menedžerji, strokovne ekskurzije. Določanje učnih strategij zahteva spretnost pri raziskovanju, ki preseže zgolj brskanje po knjižnih policah v upanju, da bomo zagledali pravi naslov.

Pod termin učna stategija uvrščamo prepoznavanje virov informacij in določanje ustreznih metod za pridobivanje teh informacij (Brečko, 2003).

Kot primere navedimo:

- Kje in kako pridobiti objavljeno gradivo, ki ga moramo uporabiti?

- Kako pridobiti informacije od kompetentnih oseb (vprašalnik, osebno, pisno)?

- Ali obstajajo manj znani viri?

- Kako preveriti pridobljene podatke in informacije?

\section{DOKAZILA O DOSEGANJU CILJA}

Končni izdelek mora pokazati, kaj je odrasli dosegel, koliko je napredoval, kakšne vire je uporabljal. Odločitev o obliki končne naloge, ki vse to dokaže, je odvisna od ciljev dogovora in ocenjevalnih meril, ki jih je treba izpolnjevati. Končni izdelek mora pokazati, da je posameznik dosegel učne cilje.

Pogosto in zelo priljubljena je seminarska na- $\log$ z $\mathrm{z}$ ustno predstavitvijo pred mentorjem in kolegi. Študent lahko s pridobljenim znanjem obogati tudi druge in poleg tega lahko razvija retorične spretnosti.

\section{VREDNOTENJE ZNANJA/ EVALVACIJA}

Namen ocenjevanja je dajanje povratne informacije študentu o njegovem napredku. Pomembno je, da so ocenjevalna merila javna in vnaprej znana. Pomembni so torej kriteriji za uspešno opravljeno nalogo. Ravno tako je potrebno določiti, kdo bo končni izdelek ocenjeval. Ponavadi to ni le svetovalec, temveč se lahko v ocenjevanje vključi več kompetentnih oseb.

\section{PREDVIDENI DATUM ZAKLJUČKA}

Kot smo že omenili pod točko operativni učni cilji, moramo tako posamezne cilje kot tudi celoten izobraževalni proces natančno časovno opredeliti z datumom. Zgolj meseci ali celo leto zaključka niso dovolj, sploh pri tistih dogovorih o samoizobraževanju, ki zadevajo daljši izobraževalni proces. Že v zgoraj navedeni točki smo opredelili, da vmesne cilje v dogovoru lahko tudi intervalno določimo.

Uvajanje metode dogovora v prakso ni lahka naloga. Pogosto se novostim ljudje upirajo, ker lahko prinašajo nepredvidljive posledice. Zato je potrebno, da metodo dogovora o samoizobraževanju formalno predvidi izobraževalna institucija. Udeležencem, ki se prvič odločajo, da bodo delali po metodi dogovora o samoizobraževanju, pomagamo tako, da najprej pripravijo lažje in kratkoročnejše načrte in šele kasneje zahtevnejše.

$\mathrm{V}$ nadaljevanju podajamo primer enostavnega načrta za samostojno izdelavo seminarske naloge. 
DOGOVOR O SAMOIZOBRAŽEVANJU - PRIPRAVA SEMINARSKE NALOGE

PRIMER: šłudent: Mojca Kosovel, mentor: dr. Jana Lisac

\begin{tabular}{|c|c|c|c|c|c|}
\hline & $\begin{array}{c}\text { OPERATIVNI } \\
\text { UČNI CILJI }\end{array}$ & $\begin{array}{c}\text { VIRI IN } \\
\text { STRATEGIJE }\end{array}$ & $\begin{array}{c}\text { DOKAZILA O } \\
\text { DOSEGANJU } \\
\text { CILJA }\end{array}$ & $\begin{array}{c}\text { VREDNOTENJE } \\
\text { ZNANJA/ } \\
\text { EVALVACIJA }\end{array}$ & $\begin{array}{l}\text { PREDVIDENI } \\
\text { DATUM } \\
\text { ZAKLJUČKA }\end{array}$ \\
\hline 1. & $\begin{array}{l}\text { poiskati širok } \\
\text { nabor literature }\end{array}$ & $\begin{array}{l}\text { obisk knjižnic: } \\
\text { Filozofska } \\
\text { fakulteta, ACS, } \\
\text { Ekonomska } \\
\text { fakulteta }\end{array}$ & $\begin{array}{c}\text { zbrana literatura } \\
\text { različnih avtorjev, } \\
\text { v različnih } \\
\text { jezikih, izpisana v } \\
\text { dispoziciji naloge }\end{array}$ & $\begin{array}{l}\text { o primernosti } \\
\text { izbrane literature } \\
\text { se posvetuje } \\
\text { s skupino } \\
\text { soudeležencev }\end{array}$ & december 2005 \\
\hline 2. & $\begin{array}{c}\text { dokazati } \\
\text { samostojno izbiro } \\
\text { in preučitev } \\
\text { literature }\end{array}$ & $\begin{array}{l}\text { branje } \\
\text { literature }\end{array}$ & $\begin{array}{c}\text { izbira } \\
\text { najprimernejše } \\
\text { literature iz } \\
\text { širokega nabora } \\
\text { in opredelitev } \\
\text { v dispoziciji } \\
\text { kot »GLAVNA } \\
\text { LITERATURA« }\end{array}$ & $\begin{array}{c}\text { mentorica ob } \\
\text { prebiranju } \\
\text { dispozicije oceni } \\
\text { primernost izbrane } \\
\text { literature (točka } 4 \text { ) }\end{array}$ & 15. december 2005 \\
\hline 3. & $\begin{array}{c}\text { samostojno } \\
\text { naštudirati } \\
\text { literaturo in } \\
\text { pripraviti izpiske }\end{array}$ & $\begin{array}{c}\text { poglobljeno branje } \\
\text { in študij literature s } \\
\text { pripravo izpiskov }\end{array}$ & pripravljeni zapiski & $\begin{array}{l}\text { samostojno oceni } \\
\text { primernosti } \\
\text { zapiskov in } \\
\text { izpiskov glede na } \\
\text { uporabnost }\end{array}$ & $\begin{array}{c}\text { konec decembra } \\
2005\end{array}$ \\
\hline 4. & $\begin{array}{c}\text { pripraviti } \\
\text { dispozicijo } \\
\text { seminarske naloge }\end{array}$ & $\begin{array}{c}\text { pisanje dispozicije } \\
\text { s pomočjo } \\
\text { literature }\end{array}$ & $\begin{array}{l}\text { dispozicija, ki jo } \\
\text { pošlje mentorici }\end{array}$ & $\begin{array}{c}\text { mentorica oceni } \\
\text { dispozicijo }\end{array}$ & 3. januar 2006 \\
\hline 5. & $\begin{array}{c}\text { osredotočiti se na } \\
\text { temo seminarske } \\
\text { naloge }\end{array}$ & $\begin{array}{c}\text { diskusija z } \\
\text { mentorico (osebna } \\
\text { ali dopisna po } \\
\text { elektronski pošti) }\end{array}$ & $\begin{array}{l}\text { zapiski diskusije, } \\
\text { ki jih kasneje } \\
\text { uporabi pri pisanju } \\
\text { naloge }\end{array}$ & $\begin{array}{c}\text { morebitna } \\
\text { vprašanja } \\
\text { prediskutira s } \\
\text { kolegi }\end{array}$ & 3. januar 2006 \\
\hline 6. & $\begin{array}{c}\text { izdelati pisni } \\
\text { izdelek - } \\
\text { seminarsko nalogo }\end{array}$ & $\begin{array}{c}\text { branje literature, } \\
\text { po potrebi dodatna } \\
\text { diskusija z } \\
\text { mentorico }\end{array}$ & $\begin{array}{l}\text { napredovanje ob } \\
\text { pisanju pisnega } \\
\text { izdelka }\end{array}$ & $\begin{array}{l}\text { pred oddajo prosi } \\
\text { kolegico za pregled } \\
\text { in pripombe }\end{array}$ & $\begin{array}{c}\text { 3. do } \\
\text { 13. januar } 2006\end{array}$ \\
\hline 7. & $\begin{array}{c}\text { oddati } \\
\text { zaključeno } \\
\text { seminarsko nalogo }\end{array}$ & $\begin{array}{l}\text { dokončanje } \\
\text { seminarske } \\
\text { naloge }\end{array}$ & $\begin{array}{c}\text { izdelana in } \\
\text { oddana seminarska } \\
\text { naloga }\end{array}$ & $\begin{array}{c}\text { mentorica } \\
\text { oceni seminarsko } \\
\text { nalogo }\end{array}$ & $\begin{array}{c}\text { oddaja: } 13 \text {. januar } \\
2006\end{array}$ \\
\hline
\end{tabular}


Dobro je, da se zavedamo, da je osebni izobraževalni načrt in verjetno tudi dogovor o samoizobraževanju sprva sprejet z negotovostjo in dvomom. Mnogi odrasli ga sprva zavračajo, ker te metode niso še nikoli prej uporabljali. To ni presenetljivo, saj smo se v vsem obdobju šolanja učili biti poučevani, nismo pa se naučili samostojnega izobraževanja. Zato se je nujno najprej z odraslim pogovoriti o izkušnjah $v$ izobraževalnem procesu in o odgovornosti, ki jo prevzemajo za svoje izobraževanje, o učenju v življenju in ne samo v procesu formalnega izobraževanja. Šele ko dojamejo, da bo na ta način izobraževanje bližje njihovim izkušnjam, interesom in predznanju, bodo morda pripravljeni sprejeti nov koncept izobraževanja. Pri tem potrebujejo primere, spodbude in oporo. Več kot imajo izkušenj s samostojnim študijem, manj bo potrebnega prepričevanja, svetovanja in vodenja.

\section{¿AKLJUČEK}

Jogovor o samoizobraževanju lahko upoabljamo na različnih stopnjah formalnega a neformalnega izobraževanja. Ko se zanj dločamo prvič, je dobro, da prej posežemo o bogati strokovni literaturi, hkrati pa priravimo in izvedemo tudi osebni načrt samozobraževanja. Tako bomo sami preizkusili retodo in s tem ugotovili, kje bi lahko poameznik naletel na težave.

eveda pa samostojnost na enem področju še e pomeni nujno samostojnosti na drugem sebinskem področju. Zato bo morda posaleznik potreboval več mentorske opore pri ompetencah, kjer začenja povsem znova in jer je bil $v$ preteklosti manj uspešen. In naprotno, dobre izkušnje in uspehi na nekem odročju lahko pomenijo večjo samostojnost 
Zakon o poklicnem in strokovnem izobraževanju (Uradni list Republike Slovenije, št. 12/96 in 44/00).

' Zakon o poklicnem in strokovnem izobraževanju (Uradni list Republike Slovenije, št. 12/96 in 44/00).

${ }^{2}$ Anketirani profesorji, predavatelji višjih strokownih šol in pristojne službe v večjih podjetjih so pilotni anketni vprašalnik prejeli po elektronski pošti in ga na isti način tudi vračali. Zbiranje podatkov je trajalo od 22. 2. 2006 do I. 3. 2006, poslanih je bilo več kot petdeset anket.

${ }^{3}$ New College, Sarasota; Empire State College, New York; Morgan State College, Mryland; State's Justin Morrill College, Michigan; New College, University of Alabama. 